\title{
Article \\ Using the Sustainable Development Goals to Evaluate Possible Transport Policies for the City of Curitiba
}

\author{
Constança Martins Leite de Almeida ${ }^{1, *}$, Semida Silveira ${ }^{2}$, Erik Jeneulis ${ }^{3}\left(\mathbb{C}\right.$ and Francesco Fuso-Nerini ${ }^{4}(\mathbb{C}$ \\ 1 School of Industrial Engineering and Management, KTH Royal Institute of Technology, \\ 11428 Stockholm, Sweden \\ 2 Sustainable Vision—Global Ventures AB, 18131 Lidingö, Sweden; semida.silveira@svision.se \\ 3 Division of Transport Planning, KTH Royal Institute of Technology, Brinellvägen 23, \\ 10044 Stockholm, Sweden; erik.jenelius@abe.kth.se \\ 4 KTH Climate Action Centre \& KTH Division of Energy Systems, School of Industrial Engineering and \\ Management, KTH Royal Institute of Technology, 8, 11428 Stockholm, Sweden; \\ francesco.fusonerini@energy.kth.se \\ * Correspondence: cmlda@kth.se
}

check for updates

Citation: Leite de Almeida, C.M.; Silveira, S.; Jeneulis, E.; Fuso-Nerini, F. Using the Sustainable Development Goals to Evaluate Possible Transport Policies for the City of Curitiba. Sustainability 2021, 13, 12222. https:/ / doi.org/10.3390/su132112222

Academic Editor: Armando Cartenì

Received: 8 September 2021

Accepted: 15 October 2021

Published: 5 November 2021

Publisher's Note: MDPI stays neutral with regard to jurisdictional claims in published maps and institutional affiliations.

Copyright: (c) 2021 by the authors. Licensee MDPI, Basel, Switzerland. This article is an open access article distributed under the terms and conditions of the Creative Commons Attribution (CC BY) license (https:// creativecommons.org/licenses/by/ $4.0 /)$.
Abstract: Cities across the world are becoming more engaged in tackling climate change and contributing to the achievement of international agreements. The city of Curitiba in Brazil is no exception. In December 2020, the city published PlanClima (Plano Municipal de Mitigação e Adaptação às Mudanças Climáticas), a climate plan developed with local and international organizations. PlanClima aims to guide policies and actions to mitigate and adapt to climate change. This study focuses on selecting and qualitatively evaluating transport policies that contribute to the city's 2030 climate and Sustainable Development Goals (SDGs). With PlanClima's analysis for the transport sector in mind, nine targets for 2030 are identified and connected to different transport policies. To evaluate the possible interactions between the policies and the different dimensions of the SDGs, four types of linkages were designed: essential, uncertain, limited, and opposite. These categories were developed to evaluate the several dimensions in which a policy can have a positive or negative impact. The results show that the implementation of zero emission zones/low emission zones, green public procurement, subsidy schemes for the uptake of clean vehicle technology, and the digitalization of the transport system through smarter public transport and digital platforms that couple bike sharing, taxis, and public transport are some of the measures that can contribute to the achievement of Curitiba's targets and ensure a positive impact on the sustainable development of the city. The study highlights how different policy instruments can contribute to achieve the city's targets, thus providing guidance to policymakers.

Keywords: transport policy; Sustainable Development Goals; climate targets; Curitiba; PlanClima

\section{Introduction}

Globally, the transport sector is responsible for the second largest share of greenhouse gas (GHG) emissions. The sector contributed $24 \%$ of direct $\mathrm{CO}_{2}$ emissions generated by fuel combustion in 2020. The rapid growth of transport sector emissions is mainly associated with road vehicles, which represent approximately three-quarters of the sector's global emissions [1]. Despite progress in electrification, and a decrease in the energy intensity of the transport sector, road transport emissions continue to increase. Therefore, an integrated, coherent, and coordinated set of policies is required to reduce the emissions of the sector. In 2015, the Paris Agreement was adopted, with the goal to reduce GHG emissions and limit global warming to well below $2{ }^{\circ} \mathrm{C}$ compared to preindustrial levels. Since then, 192 countries have made commitments to reduce emissions, as elaborated in their nationally determined contributions (NDCs) [2]. However, as most of the world population is concentrated in urban areas, the achievement of the NDCs depends on the engagement of local governments [3]. 
During the United Nations (UN) summit in 2015, heads of state and governments adopted Agenda 2030. The Agenda consists of 17 Sustainable Development Goals (SDGs) with 169 targets [4]. The SDGs focus on stimulating action for people, the planet, prosperity, peace, and partnerships. All these components have an integrated and interlinked nature that is crucial to the purpose of the SDGs. Five targets can be directly connected to the transport sector and several others can be indirectly related [5]. Therefore, the challenges faced by the transport sector, including congestion, road safety, energy consumption, pollution, can be connected to and evaluated within the context of these SDGs.

The SDGs and the NDCs are particularly intertwined in SDG 13, climate action, indicating the global recognition of the importance of addressing climate change and its impacts. In the past, several papers have been written in order to capture the interactions between sustainable development and transport policies. In 2012, an article described the interactions between policies targeting energy use in road passenger transport to reduce petroleum consumption and GHG emissions and sustainable development targets [6]. In 2020, an article demonstrated how integrated interventions for placemaking and active transport can contribute to a wide range of SDG targets [7].

Over the last few decades the engagement of cities in tackling climate change and ensuring a sustainable development has become crucial [8,9]. Despite their limited legal status under international law and sometimes autonomously from their nation state, cities have intensified their actions to reduce emissions and incentivize sustainable development. This has been incentivized by the construction of networks active in sustainable urban development and climate change, for example the C40 Cities Climate Leadership Group [10] or the Local Governments for Sustainability (ICLEI) [11]. C40 is a network of large cities around the world pursuing the common goal to reduce GHG and mitigate local and global climate risks through meaningful, measurable, and sustainable actions [10]. The city of Curitiba, in Brazil, joined this network in 2005 and under the Deadline 2020 initiative, developed a municipal plan to mitigate and adapt the city to climate change called "Plano Municipal de Mitigação e Adaptação às Mudanças Climáticas" (PlanClima) [12].

Curitiba is the capital of the state of Paraná, a southern Brazilian city of 1.9 million inhabitants with a metropolitan population of 3.2 million [13]. The city has a long history of innovative sustainable urban planning, particularly due to the introduction of the worldfamous bus rapid transit (BRT) concept [14]. The BRT system was designed in the 1970s, consisting of special high-capacity buses running on fully dedicated lanes [14]. Today, Curitiba is a world reference for urban planning and smart environmental initiatives [15].

At present, to the best of the authors' knowledge, few research studies have investigated how local transport plans can be translated into policy making that aims to achieve both climate and sustainable development goals. This paper aims to fill this research gap, by focusing on the transport sector of the city of Curitiba. The study starts by identifying the main targets of the city's transport sector as expressed in PlanClima, and qualitatively evaluating possible policies for their achievement. In this way, this study aims to recommend possible policies to fulfil the goals present in PlanClima. Following this introduction, which also includes an overview of Planclima, Section 2 describes the applied methodology. In Section 3, the goals of PlanClima for the transport sector are translated into nine targets and policies are researched to fulfill these targets. In Section 4, the results are discussed. Finally, in Section 5, conclusions and policy recommendations for the policymaking of the city are presented.

\section{PlanClima}

PlanClima was published in December 2020 with the purpose of guiding the actions and policymaking of the city of Curitiba to mitigate and adapt it to climate change. One of the sectors that PlanClima addresses is the transport sector, which is responsible for $66.6 \%$ of the city's GHG emissions [12]. Within the plan, three scenarios were developed and this study focusses on scenario "estendido" (extended scenario). In this scenario a reduction of $78.1 \%$ of the city's emissions by 2050 , compared to the levels of 2016 , is 
modeled. To ensure this level of GHG emissions reduction, different actions, mitigation goals, and assumptions are described in PlanClima [12]. As can be seen in Table 1, for the transport sector, PlanClima focuses on fuel and technology changes for passenger cars, and a shift among the different modes of transport. Both of the assumptions, fuel switch and modal shift, have been designed with intermediate goals for 2030. For the fuel and technology changes, an introduction of electricity- and hydrogen-powered vehicles by 2030 is expected, with a combined share of $30 \%$ of all passenger cars by the end of the decade. For the modes of transport, an increase in trips by foot and by bicycle is expected, in combination with the introduction of a high capacity public transport system and a decrease in car travel. In PlanClima, a high capacity public transport system, is referred to as a public transport system with a higher capacity than the BRT.

Table 1. Technological assumptions and mitigation goals present in PlanClima for scenario "estendido".

\begin{tabular}{|c|c|}
\hline Mitigation Goals & Technological Assumptions 2030 \\
\hline $\begin{array}{l}\text { 2050: } 100 \% \text { of the transport sector } \\
\text { fueled by clean or renewable energy }\end{array}$ & $\begin{array}{l}\text { Fuel and technology shift for passenger cars } \\
\text { from } 2016 \text { to } 2030 \text {. } \\
\text { Fuel mix in 2030: ethanol, gasoline, electricity, } \\
\text { and hydrogen. } \\
\text { - } \quad \text { Phase out diesel and compressed } \\
\text { natural gas } \\
\text { - Introduce battery electric vehicles } \\
\text { (BEVs) and achieve a share of } \\
\text { approximately } 20 \% \text {; } \\
\text { - Introduce fuel cell electric vehicles } \\
\text { (FCEVs) and achieve a share of } \\
\text { approximately } 8 \% \\
\text { - Increase the share of ethanol from } \\
\text { approximately } 40 \% \text { to } 50 \% \\
\text { Decrease the share of gasoline fueled } \\
\text { vehicles to approximately } 23 \%\end{array}$ \\
\hline
\end{tabular}

Modes of transportation:

- Introduce a high capacity transport system and achieve approximately a share of $12 \%$ of all trips

- $\quad$ Reduce the percentage of car trips from $46 \%$ to $29 \%$

- Increase the share of trips made by foot and by bicycle from approximately $25 \%$ to $31 \%$

2050: $85 \%$ of transportation should be completed through public transportation or active mobility
- Increase the share of trips made by motorcycle

- Increase the share of trips made by taxi

- $\quad$ Slightly decrease the share of buses and minibuses and replace them by the Bus Rapid Transit system and a high capacity public transport system in order to reduce the existent overlap of lines and routes

\section{Technological Assumptions 2050}

Fuel and technology shift for passenger cars from 2030 to 2050.

Fuel mix in 2050: ethanol, electricity, and hydrogen.

- $\quad$ Phase out gasoline

- Increase the share of battery electric vehicles (BEVs) from approximately $20 \%$ to $70 \%$

- Increase the share of fuel cell electric vehicles (FCEVs) from approximately $8 \%$ to $15 \%$

- Decrease the share of ethanol vehicles from approximately $50 \%$ to $15 \%$

Modes of transportation:

- Increase the high capacity public transport system from $12 \%$ to $25 \%$

- $\quad$ Reduce the percentage of car trips from $29 \%$ to $6 \%$

- Increase the share of trips made by foot and bicycle from approximately $31 \%$ to $38 \%$

- $\quad$ Slightly increase the share of trips made by motorcycle

- Increase the share of trips made by taxi from approximately $2 \%$ to $6 \%$

- Decrease the share of bus and mini buses and replace them by the Bus Rapid Transit system and the high capacity transport system in order to eliminate the existent overlap of lines and routes

- Increase the share of trips made through the Bus Rapid Transit system from $8 \%$ to $12 \%$

PlanClima encompasses a list of 20 actions, from which three focus exclusively on the transport sector: expanding low carbon measures for the planning and management of the cities' mobility; promoting active mobility, mainly by bicycle and by foot, through the improvement, expansion, and integration of services and infrastructure for bicycles and pedestrians; and promoting the renewal of the public transport fleet with the goal 
to decarbonize and improve the cities' accessibility, air quality, and thermic comfort of the passengers [12]. In PlanClima, each of these actions is connected to the SDGs that it can potentially affect, however, no explanation is provided for the linkages established. For scenario "estendido", three main assumptions were made in PlanClima: an increase in vehicle efficiency; a significant increase in trips made by public transport and active mobility; and a significant decrease in the number of trips made by car. As can be seen in Table 1 two mitigation goals were defined for 2050 and in order to develop scenario "estendido" technological assumptions of fuel and technology shifts and distribution of modes of transport were made. Table 1 shows that the goal of scenario "estendido" is ambitious; in order to accomplish it a change in mobility paradigms, processes, behaviors, and technologies will be needed.

\section{Methodology}

In order to conduct this study four main steps were taken, as shown in Figure 1. As a first step the actions, mitigation goals, and technological assumptions, present in PlanClima, that apply exclusively to the transport sector, were identified. From these, nine targets were defined in order to capture the largest changes that need to occur by 2030 to achieve scenario "estendido" of PlanClima. For each of the nine targets, keywords were selected, based on the wording of each target, and a literature review was conducted to identify policies that can contribute to the achievement of each target. In addition, a literature review of existing transport policies was undertaken, and six keywords/phrases were selected: transport, policies, decarbonization of the transport sector, review of policies, citylevel policies, and sustainable development. Several combinations of these keywords were researched, and the corresponding articles and reports were reviewed. The reviews were obtained using Google scholar, and a cap of 20 papers was imposed for each search. The papers and reports analyzed were from 2000 to 2021.

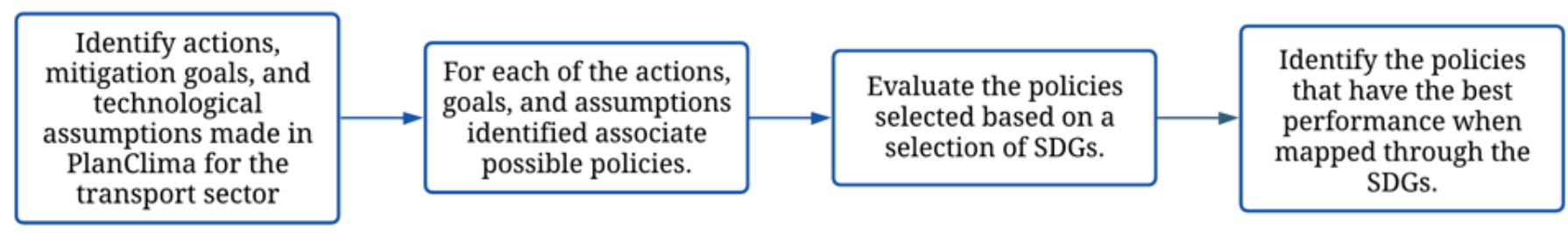

Figure 1. Workflow used to develop this study.

As a third step, the policies previously selected were divided into three categories (economic, regulatory, and information) according to the taxonomy develop by [16]. The SDGs were used as a lens to evaluate each selected policy, since different dimensions of the transport sector can be captured through different SDGs. In Figure 2, each of the dimensions evaluated can be seen. A selection of SDGs was made based on the ones highlighted for the transport sector in PlanClima and the different dimensions that could be evaluated through the SDGs. In this way, SDG 1, 3, 4, 7, 8, 9, 10, 11, 12, 13, 16, and 17 were selected. The impact on GHG emissions was captured using SDG 13 (Climate Action).

To assess each policy a systematic mapping of literature $[17,18]$ was conducted in order to answer the question: How can each of the policies influence the dimensions captured by each SDG? To this end, studies were mapped to capture possible interactions between the policies identified in step 2 and the different dimensions of the SDGs. In order to map the studies, the words used to formulate the targets and the SDGs dimensions were defined as a research criterion. For the material collection, Google was selected in order to access both peer-reviewed articles and grey literature. Google scholar was used to find and select literature published in academic journals, and it was aided by Google search for finding and assessing grey literature. As grey literature, reports by international organizations, national, and subnational agencies were considered. The method used was adapted from previous studies evaluating SDGs linkages $[19,20]$. 


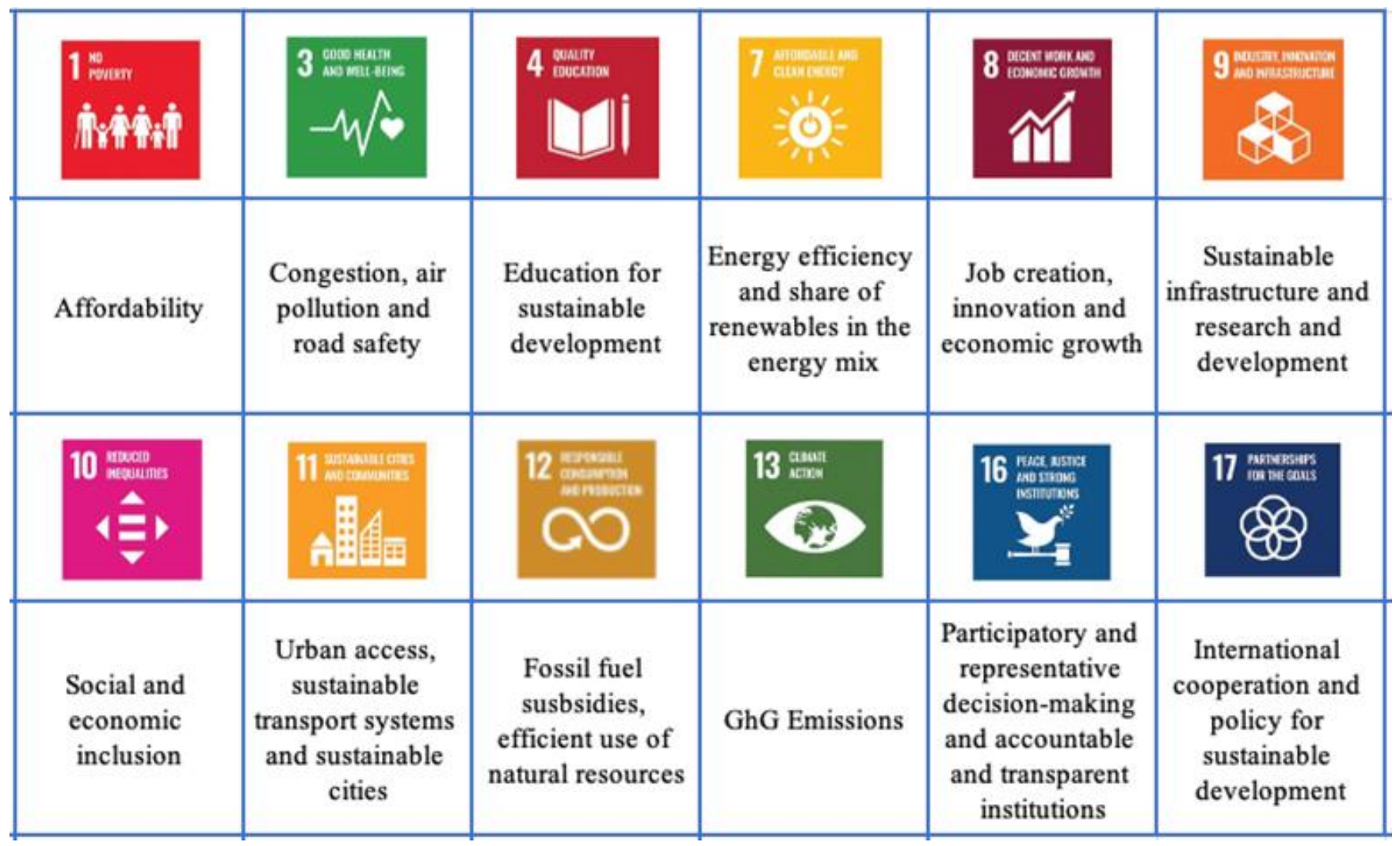

Figure 2. Dimensions of the transport sector captured by each SDG.

To evaluate the possible interactions between the policies and the dimensions of the SDGs, four types of linkages were designed: essential, uncertain, limited, and opposite. This was delineated based on the work developed by [6]. These categories were developed to evaluate the several dimensions in which a policy can have a positive or negative impact. Each category is based on the level of scholarly agreement identified within the mapping of literature and the availability of existing examples of implementation. An essential interaction (green color) reflects strong academic agreement of a positive impact between the policy and the dimension analyzed and the existence of successful implementation examples. Therefore, this interaction was identified when one or more peer reviewed articles or reports were found, and a case of implementation was documented. In order to identify this linkage no literature describing a negative interaction could be found. Uncertain (yellow color) indicates that a degree of disagreement in the area is apparent, with some cases of implementation proving to have a positive impact and others a negative impact. In this case if at least a positive and a negative article or report were identified this interaction was established. Limited interaction (orange color) indicates that no studies connecting the dimension and the policy were found. Finally, an opposite interaction (red color) reflects a negative impact of the policy towards an SDG dimension, in this case one study documenting a negative interaction was needed. In addition, no studies documenting a positive impact, or a lack of correlation between the policy and the dimension could be found. As a final step, based on the mapping of the policies, a recommendation of policies to achieve the city goals was made. 


\section{Targets and Policies}

Based on the actions, assumptions, and mitigation goals present in PlanClima, nine targets were defined in order to summarize the main objectives for Curitiba's transport sector by 2030. These will ensure that Curitiba is on track with the achievement of scenario "estendido" by 2050. The nine targets defined were:

1. Increase vehicle efficiency;

2. Promote active mobility (pedestrians and cycling);

3. Reduce the share of trips made by car;

4. Promote the use of public transport through both the bus rapid transit system and the high capacity transport system;

5. Phase out compressed natural gas-fueled vehicles;

6. Phase out diesel-fueled vehicles;

7. Decrease the share of gasoline-fueled vehicles;

8. Promote the introduction of battery electric vehicles (BEVs);

9. Promote the introduction of fuel cell electric vehicles (FCEVs).

For each of the nine targets, a literature review of existing transport policies that can contribute to the achievement of each target was undertaken. During this search, articles and reports encompassing compilations and local implementations of transport policies that fulfill the targets were found. Table 2 shows the targets and corresponding regulatory, economic, and information policy instruments. As can be observed in Table 2, the policies that promote active mobility do not necessarily target walking and cycling per se, but instead have an indirect effect by discouraging automobile travel, which can create better conditions for walking and cycling. The same can be seen in "decreasing gasoline fueled vehicles" and "incentivizing battery electric vehicles (BEVs) and fuel cell electric vehicles (FCEVs)". Among the different policies, green public procurement, implementation of stricter emission standards, implementation of Zero Emission Zones (ZEZs)/ Low Emission Zones (LEZs), and development of public awareness and information campaigns are associated with the highest number of targets, four or more. These policies are mainly related to targets that aim to reduce, phase out, or incentivize certain technologies.

Table 2. Targets identified in PlanClima and corresponding policies that aim to fulfill them.

\begin{tabular}{|c|c|}
\hline Aim of the Policy & Possible Policies \\
\hline $\begin{array}{l}\text { Increase the efficiency of } \\
\text { vehicles }\end{array}$ & $\begin{array}{ll}\text { - } & \text { Fuel economy vehicle standards } \\
\text { - } & \text { Provide funding for R\&D in vehicle efficiency } \\
\text { - } & \text { Provide tax incentives to encourage production and purchase of higher-efficiency vehicles } \\
\text { - } & \text { Implement fuel economy labeling } \\
\text { - } & \text { Provide low interest loans for the purchase of fuel efficient vehicles } \\
\text { - } & \text { Introduce extra fees for ineficient vehicles (feedbates) } \\
\text { - } & \text { Promote eco-driving } \\
\text { - } & \text { Provide funding for the development of intelligent and connected vehicles } \\
\text { - } & \text { Provide subsidies for energy efficient vehicles }\end{array}$ \\
\hline $\begin{array}{l}\text { Incentivize the use of } \\
\text { public transportation } \\
\text { through both the bus rapid } \\
\text { transit system and the high } \\
\text { capacity transport system }\end{array}$ & $\begin{array}{l}\text { - Lowering (or completely removing) public transport fares } \\
\text { - Provide funding for new technologies to supply favorable services, such as an SMS ticket and } \\
\text { downloadable public transport maps or timetables } \\
\text { - } \quad \text { Public awareness and information campaigns to incentivize the use of public transportation } \\
\text { - Providing financing for public transport }\end{array}$ \\
\hline $\begin{array}{l}\text { Promote active } \\
\text { mobility }\end{array}$ & 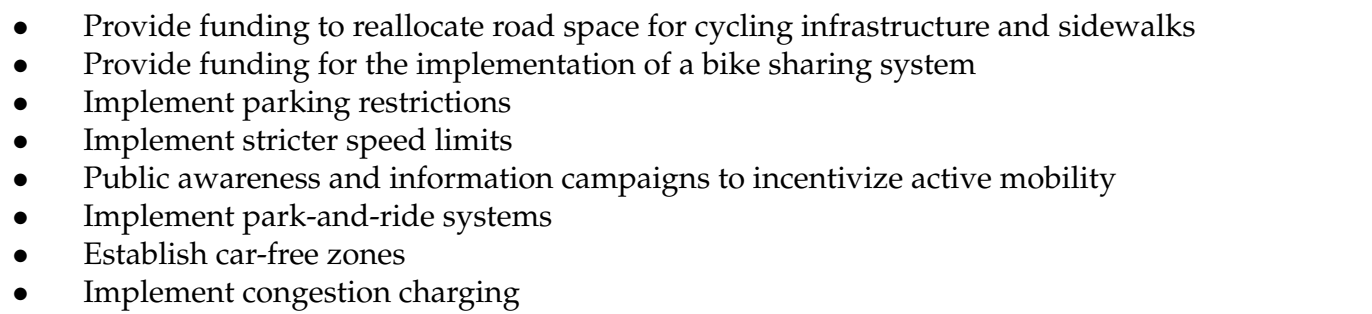 \\
\hline
\end{tabular}


Table 2. Cont.

\begin{tabular}{|c|c|}
\hline Aim of the Policy & Possible Policies \\
\hline $\begin{array}{l}\text { Decrease the share of } \\
\text { gasoline-fueled vehicles }\end{array}$ & $\begin{array}{l}\text { - Implement tax schemes for gasoline-fueled vehicles } \\
\text { - } \quad \text { Green public procurement } \\
\text { - } \quad \text { Implement Zero Emission Zones/Low Emission Zones } \\
\text { - Implement emission standards } \\
\text { - Implement higher road tolls for new fossil-fuel cars } \\
\end{array}$ \\
\hline $\begin{array}{l}\text { Decrease the share of trips } \\
\text { made by car }\end{array}$ & $\begin{array}{ll}\text { - } & \text { Implement Zero Emission Zones/Low Emission Zones } \\
\text { - } & \text { Establish partial traffic bans based on time windows } \\
\text { - } & \text { Implement congestion charging } \\
\text { - } & \text { Provide funding to reallocate road space to cycling infrastructure and sidewalks } \\
\text { - } & \text { Establish car-free zones }\end{array}$ \\
\hline $\begin{array}{l}\text { Incentivize the } \\
\text { introduction of battery } \\
\text { electric vehicles (BEVs) }\end{array}$ & $\begin{array}{l}\text { - } \quad \text { Provide funding for self-service electric car hire scheme } \\
\text { - } \quad \text { Implement Zero Emission Vehicle mandates } \\
\text { - } \quad \text { Provide subsidies for BEVs } \\
\text { - } \quad \text { Free Parking for BEVs } \\
\text { - } \quad \text { Public awareness and information campaigns to incentivize the purchase of BEVs } \\
\text { - } \quad \text { Implement emissions standards }\end{array}$ \\
\hline $\begin{array}{l}\text { Incentivize the } \\
\text { introduction of fuel cell } \\
\text { electric vehicles (FCEVs) }\end{array}$ & $\begin{array}{ll}\text { - } & \text { Implement Zero Emission Vehicle mandates } \\
\text { - } & \text { Provide subsidies for FCEVs } \\
\text { - } & \text { Provide funding for the expansion of hydrogen refueling infrastructure } \\
\text { - } & \text { Free Parking for FCEVs } \\
\text { - } & \text { Public awareness and information campaigns to incentivize the purchase of FCEVs } \\
\text { - } & \text { Implement emissions standards } \\
\text { - } & \text { Green public procurement }\end{array}$ \\
\hline $\begin{array}{l}\text { Phase out compressed } \\
\text { natural gas (CNG) vehicles }\end{array}$ & $\begin{array}{ll}\text { - } & \text { Implement Zero Emission Vehicle mandates } \\
\text { - } & \text { Implement tax schemes for CNG vehicles } \\
\text { - } & \text { Impleen public procumrement Low Emission Zones / Zero Emission Zones } \\
\text { - } & \text { Implement emissions standards }\end{array}$ \\
\hline $\begin{array}{c}\text { Phase out diesel-fueled } \\
\text { vehicles }\end{array}$ & $\begin{array}{ll}\text { - } & \text { Implement Zero Emission Vehicle mandates } \\
\text { - } & \text { Implement tax schemes for diesel vehicles } \\
\text { - } & \text { Impleen public procurement } \\
\text { - } & \text { Implement emission standards }\end{array}$ \\
\hline
\end{tabular}

\section{Evaluation of Policies through the SDGs}

The policies identified were divided into regulatory, economic, and information policy instruments, according to the taxonomy developed by [16]. These policies were then mapped using the SDG dimensions, which can be seen in Figure 2. For this, the selection of SDGs shown in Figure 2 was used, with SDG 13 (climate action) representing the reduction in GHG emissions. Each policy was evaluated based on the SDG dimensions, by using four different categories: essential (green), uncertain (yellow), limited (orange), and opposite (red). However, this method does not capture possible interactions between different policies, since it only evaluates each policy individually.

\subsection{Regulatory Policy Instruments}

Figure 3 shows the selected regulatory policy instruments. These policies encompass vehicle standards, vehicle access restrictions, and planning and infrastructure design. From all the policies mapped, implementation of stricter emissions standards; implementation of 
ZEZs/LEZs; and reallocation of road space for public transport, bicycles and pedestrians are the policies that perform the best within the different dimensions of the SDGs.

As can be seen in Figure 3, stricter emission standards is the policy with the most documented and academic agreement of positive interactions. The implementations of tighter emission standards can have a significant influence in reducing $\mathrm{CO}, \mathrm{HC}, \mathrm{NO}$, and smoke (particulate) emissions, which can contribute to a significant decrease in air pollution in cities [21]. However, depending on the design of the standards it may also have an increase in one of the above pollutants [21]. Nevertheless, this measure has been shown to significantly reduce air pollution in cities around the world [21-24]. By increasing the stringency of the standards, the deployment of progressively more effective and sophisticated technologies is needed. For example, diesel engine development for road vehicles has been mainly driven by more stringent emission standards [25]. The main shortcoming of this policy is that it may not contribute to an effective reduction in $\mathrm{CO}_{2}$ emissions [24]. Even though this could be a possible policy to implement in Curitiba, the emission standards in Brazil are set by the federal government and not by the states or cities [26]. Nevertheless, this policy is currently being implemented in Brazil with the 2018 "Programa de Controle de Poluição do Ar por Veículos Automotores (PROCONVE)". This includes two new emission standards, L-7 and L-8, which will come into force in 2022 and 2025, respectively [26].

\begin{tabular}{|c|c|c|c|c|c|c|c|c|c|c|c|c|}
\hline & so61 & SOG3 & SOG4 & SDG7 & 5068 & soG9 & SOG10 & SDG11 & soG12 & SDG13 & SDG16 & SOG17 \\
\hline \multicolumn{13}{|l|}{ Implement stricter emission standards } \\
\hline \multicolumn{13}{|l|}{$\begin{array}{l}\text { Implement stricter fuel economy vehicle } \\
\text { standards }\end{array}$} \\
\hline \multicolumn{13}{|c|}{$\begin{array}{l}\text { Introduce driving restrictions through license } \\
\text { plate restrictions }\end{array}$} \\
\hline \multicolumn{13}{|c|}{$\begin{array}{l}\text { Implementzero Emission Zones/Low Emission } \\
\text { Zones (ZEZ/LZZS) }\end{array}$} \\
\hline \multicolumn{13}{|l|}{ Reallocate road space to public transport } \\
\hline \multicolumn{13}{|l|}{$\begin{array}{l}\text { Reallocating road space to occling and } \\
\text { pedestrian infrastructure }\end{array}$} \\
\hline \multicolumn{13}{|l|}{$\begin{array}{l}\text { Implement Zero Emission Vehicles (ZEV) } \\
\text { mandates }\end{array}$} \\
\hline \multicolumn{13}{|l|}{ Establish car-free zones } \\
\hline \multicolumn{13}{|l|}{ Implement parking restrictions } \\
\hline \multicolumn{13}{|l|}{$\begin{array}{l}\text { Establish partial traffic bans based on time } \\
\text { windows }\end{array}$} \\
\hline \multicolumn{13}{|l|}{ Implement park and ride systems } \\
\hline Implement stricter speed limits & & & & & & & & & & & & \\
\hline
\end{tabular}

Figure 3. Mapping of regulatory policy instruments. Four colors were used: green represents strong academic agreement of a positive effect between the policy and the SDGs, yellow means uncertainty, orange denotes a lack of specific studies in the area, and red represents a negative effect between the policy and the SDGs.

Implementation of Zero Emission Zones/Low Emission Zones (ZEZs/LEZs) is another policy with documented positive impacts in several SDG dimensions. This measure can potentially reduce particulate matter and NOx emissions in the areas under the ZEZs/LEZs [27-30] and incentivize companies and individuals to adopt cleaner vehicles [30,31]. In addition, it can foster innovation in city logistics and boost modernization [31]. However, in order to achieve relevant results and avoid spillover a city-wide scheme should be implemented [32]. Additionally, GHG emissions may be reduced depending on the design of the ZEZs/LEZs policy. This will mostly depend on whether the measure will result in fewer vehicles, better traffic flows, and the uptake of zero or low emission vehicles (ZEVs/LEVs) [33]. Similar to ZEZs/LEZs, reallocating road space to bicycles, pedestrians, and public transport can contribute to the reduction in air pollution [34]. Moreover, this policy can contribute to the development of infrastructure that ensures a more sustainable city. Furthermore, increasing the walkability of cities and the quality of public transport can also contribute to social inclusion $[35,36]$. The reduction in GHG 
through this policy will highly depend on the adoption of cycling, walking, and public transport by the population. In the Brazilian context, the lack of cycling infrastructure has been highlighted as one of the main barriers for students not to cycle [37]. Therefore, the implementation of this policy could promote active mobility. In Curitiba, there is a municipal plan being implemented that aims to build $408 \mathrm{~km}$ of bike lanes by 2025 [38]. In addition, Curitiba was the pioneer in the implementation of the BRT (Bus Rapid Transit) and is currently increasing BRT capacity and velocity through the expansion of the Inter 2 line [39]. This gives the city an advantage in implementing a successful high capacity transport system.

Restrictions through license plates was the only policy with strongly documented negative effects regarding any SDG dimension. For this policy measure, a tradeoff with SDG 16, participatory and representative decision making was found. In an article, after the implementation of this policy, $47.8 \%$ of the regulated car owners did not follow the restrictions and drove illegally to their destination places [40].

\subsection{Economic Policy Instruments}

In terms of economic policy instruments, taxes, subsidies, financing, and pricing instruments were found in the literature. Subsidies for ZEVs and energy efficient vehicles, taxes for fossil-fueled vehicles, lower or total removal of public transport fares, and providing funding for the implementation of bike-sharing systems are the policies with the most positive linkages. As illustrated in Figure 4, subsidies for ZEVs and energy efficient vehicles have positive linkages with several SDGs. For example, it can contribute to the reduction in air pollution in cities, mainly $\mathrm{NH}_{3}, \mathrm{NOx}$, and $\mathrm{PM}_{2.5}$ [41], incentivize the uptake of energy efficient vehicles, and increase the amount of renewable energy in the energy mix. This policy may also have a positive impact on SDG 13, however this will depend on the emission intensity of the electricity used to power the BEVs or produce hydrogen [42]. In 2015, Curitiba had a carbon intensity of the electricity grid of $35 \mathrm{TonCO}_{2} \mathrm{e} / \mathrm{TJ}$ and Brazil had a share of approximately $66 \%$ of renewable energy in the electricity grid $[43,44]$. Subsidies for ZEVs and energy efficient vehicles is not designed with any specific goal of social equity, however any potential wealth disparity in accessing the subsidies could be addressed by instituting an income cap [45].

The implementation of a fuel tax will hinder affordability of transport and may contribute towards the social exclusion of the lowest classes [46]. Nevertheless, it may have a positive impact on the air pollution levels, GHG emissions, and incentivize a more sustainable consumption [47]. In contrast, lowering or totally removing public transport fares will contribute to social inclusion, through the mobility improvement of low-income people $[48,49]$, and the affordability of the transport sector. However, there is limited evidence that there will be less automobile traffic, significant mode shifts to public transport, or less traffic congestion [50]. An undesired shift from walking or biking to public transport is also reported in different cities that applied this measure [48,50,51]. Funding for the implementation of bike-sharing systems can also expand active mobility [52] and in combination with the increase in infrastructure contribute to an increase in cycling. Other measures such as providing funding for smarter public transport, can contribute to an increase in the usage of public transport and the attainment of SDG 8, decent work and economic growth, and SDG 11, sustainable cities and communities. The two previous policies in combination with digital platforms that provide the integration of all mobility services, including bike-sharing, taxis, and public transport can foster multimodal mobility [53]. 


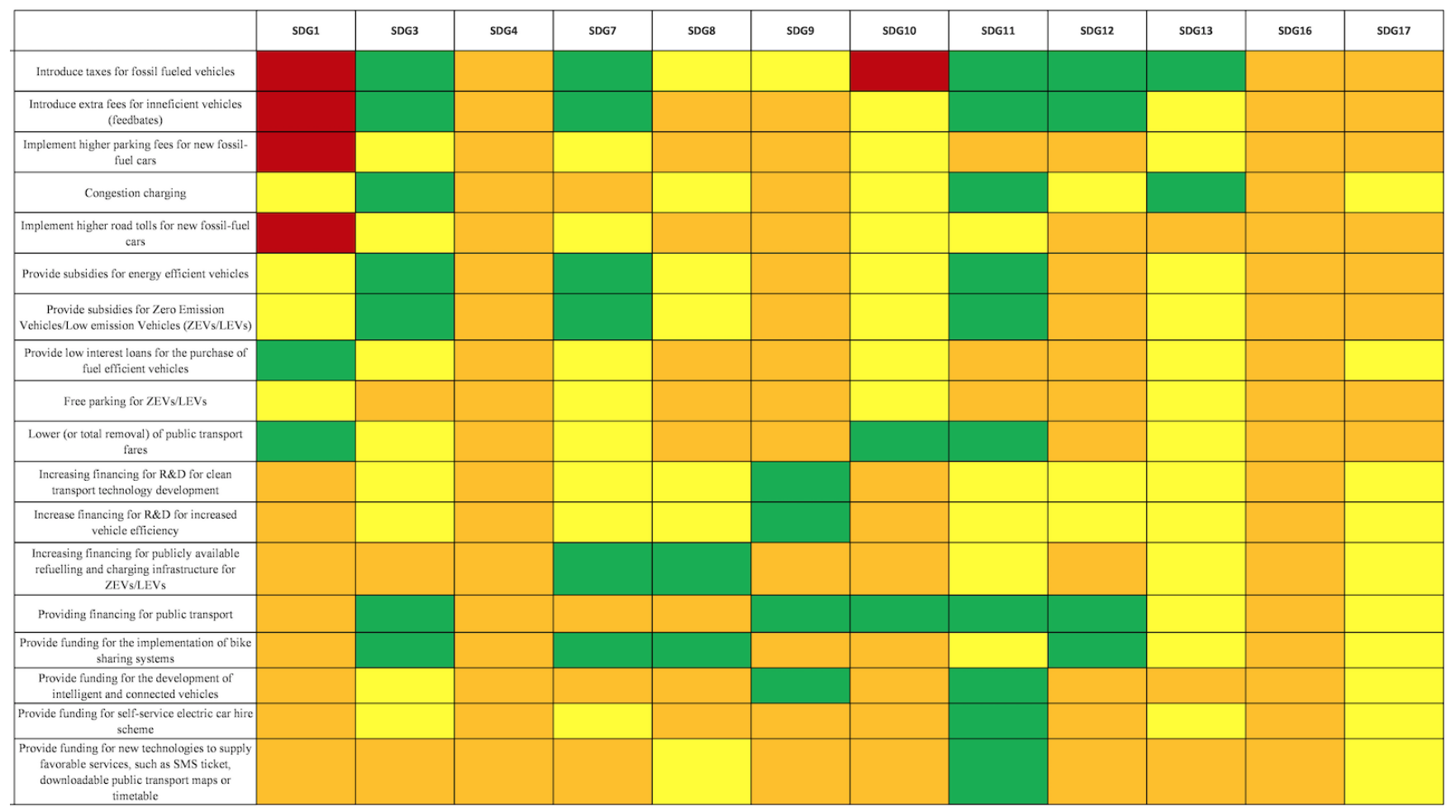

Figure 4. Mapping of economic policy instruments. Four colors were used: green represents strong academic agreement of a positive effect between the policy and the SDGs, yellow means uncertainty, orange denotes a lack of specific studies in the area, and red represents a negative effect between the policy and the SDGs.

\subsection{Information Policy Instruments}

As shown in Figure 5, several information policies were analyzed: standards (labelling), awareness campaigns, information provision, knowledge creation, and education. From these, both eco-driving and green public procurement, may have positive effects in reducing GHG emissions and air pollution [54-57]. However, awareness campaigns for eco-driving can have a short-term effect with drivers returning to their habitual behaviors [56]. This can be mitigated with dynamic eco-driving, where advice, depending on the traffic conditions, is given in realtime to drivers through the help of realtime traffic sensing and telematics [55]. Green public procurement can be a useful tool for cities, since it uses municipality purchasing power to shape the transport system into a more sustainable one [58]. A possible implementation of this measure is the introduction of ZEVs/LEVs in the bus fleet. However, the impact of this policy may vary significantly depending on how strictly the municipalities choose to set the requirements [59].

\begin{tabular}{|c|c|c|c|c|c|c|c|c|c|c|c|c|}
\hline & SDG1 & SDG3 & SDG4 & SDG7 & sDGs & SDG9 & SDG10 & SDG11 & SDG12 & SDG13 & SDG16 & SDG17 \\
\hline \multicolumn{13}{|l|}{$\begin{array}{c}\text { Public awareness and information campoigns to } \\
\text { incentivize the use of public transportation } \\
\text { in }\end{array}$} \\
\hline \multicolumn{13}{|l|}{\begin{tabular}{|c|}
$\begin{array}{c}\text { Public awareness and information campaigns to } \\
\text { incentivize active mobility }\end{array}$ \\
\end{tabular}} \\
\hline \multicolumn{13}{|l|}{$\begin{array}{l}\text { Public awareness and information campaigns to } \\
\text { incentivize the purchase of clean vehicles }\end{array}$} \\
\hline \multicolumn{13}{|l|}{ Introduce campaigns to promote eco-diving } \\
\hline \multicolumn{13}{|l|}{ Green public procurement } \\
\hline Implement fuel economy labeling (FEL) & & & & & & & & & & & & \\
\hline
\end{tabular}

Figure 5. Mapping of information policy instruments. Four colors were used: green represents strong academic agreement of a positive effect between the policy and the SDGs, yellow means uncertainty, orange denotes a lack of specific studies in the area, and red represents a negative effect between the policy and the SDGs. 


\section{Conclusions and Policy Recommendations}

In this paper, 36 policies were evaluated qualitatively using a selection of SDGs. From these policies, the ones that performed the best, within the different SDG dimensions, were discussed for the context of Curitiba. This aims to provide policymakers with different policy instruments that can enable the achievement of Curitiba's 2030 climate and sustainable goals. The policies were divided into regulatory, economic, and information. Out of the regulatory policy instruments, stricter emissions standards, implementation of ZEZs/LEZs, and reallocation of road space for public transport, bicycles, and pedestrians were the ones with the most positive linkages with the SDGs. The implementation of ZEZs/LEZs is the measure that can influence the largest number of targets defined in PlanClima. Therefore, a quantitative study should be conducted in order to design ZEZs/LEZs that maximize the goals present in PlanClima and avoid possible spillover. Reallocation of road space for public transport, bicycles, and pedestrians is being implemented by Curitiba with the Plano de Estrutura Cicloviária, which aims to build $408 \mathrm{~km}$ of bike lanes by 2025. In addition, the long tradition of urban planning in Curitiba gives the city the required knowledge to expand the BRT and implement a high capacity transport system. Nevertheless, these two modes of transport will need to represent approximately $23 \%$ of the total number of trips made in Curitiba in 2030, which would entail the creation/expansion of lines and/or the increase in capacity of existent lines.

Among the economic policies, fuel taxes, subsidies for energy efficient vehicles or ZEVs/LEVs, and total removal/lowering of public transport fares were analyzed. Fuel taxes and total removal/ lowering of public transport fares had different positive and negative linkages. Fuel taxes had possible positive impacts in the reduction in air pollution and GHG emissions and removal/lowering the public transport fares contributed to social inclusion. However, removing/lowering the public transport fares had very little evidence of reducing air pollution or GHG emissions. Nevertheless, several designs for this measure exist, and depending on the city, it can have very different outcomes, therefore quantitative studies should be conducted. Regarding the implementation of subsidies, different levels of subsidies should be analyzed in order to make the purchase of ZEVs/LEVs competitive in comparison to internal combustion. At the same time, equality in obtaining the subsidies should be maximized, for example, by implementing income caps for accessing the subsidies. In order for the introduction of ZEVs/LEVs to be successful, charging infrastructure should be available in different locations of the city. Promoting active mobility through bike-sharing systems in combination with digital platforms that couple bike-sharing, taxis, and public transport can be another measure to implement in Curitiba. Digitalization that contributes to a smarter public transport and multimodal mobility can be an enabler of a more sustainable transport system for the city of Curitiba.

Green public procurement is another policy that can have an impact on a high number of targets. This could be implemented, for example, through the procurement of buses or refuse trucks fueled by electricity or hydrogen. In this way, green public procurement can contribute to the uptake of clean technology and the decarbonization of the city.

Further research should be developed in order to quantitatively assess each recommended policy and design it to maximize the achievement of the targets defined in PlanClima. In addition, the interactions between different policies should be studied, since in some cases it can highly influence their performance.

Author Contributions: Conceptualization, C.M.L.d.A. and F.F.-N.; methodology, C.M.L.d.A.; formal analysis C.M.L.d.A.; writing-original draft preparation, C.M.L.d.A.; writing-review and editing, C.M.L.d.A., S.S., E.J. and F.F.-N. All authors have read and agreed to the published version of the manuscript.

Funding: This paper was written in the scope of a collaboration between Swedish and Brazilian partners in the project "Smart City Concepts in Curitiba-low-carbon transport and mobility in a digital society" funded by VINNOVA (Governmental Agency for Innovation Systems) in Sweden.

Institutional Review Board Statement: Not applicable. 
Informed Consent Statement: Not applicable.

Data Availability Statement: Not applicable.

Conflicts of Interest: The authors declare no conflict of interest.

\section{References}

1. IEA. Tracking Transport 2020-Analysis-IEA. 2020. Available online: https:/ /www.iea.org/reports/tracking-transport-2020 (accessed on 7 September 2021).

2. UNFCCC. Nationally Determined Contributions (NDCs) I UNFCCC. Available online: https://unfccc.int/process-and-meeti ngs/the-paris-agreement/nationally-determined-contributions-ndcs/nationally-determined-contributions-ndcs (accessed on 7 September 2021).

3. UN-Habitat. Enhancing Nationally Determined Contributions through Urban Climate Action; UN-Habitat: Nairobi, Kenya, 2020.

4. U. Nations. THE 17 GOALS I Sustainable Development. Available online: https://sdgs.un.org/goals (accessed on 7 September 2021).

5. UNESCAP. Transport and Sustainable Development Goals Transport and Communications Bulletin for Asia and the Pacific Economic and Social Commission for Asia and the Pacific; UNESCAP: Bangkok, Thailand, 2017.

6. Figueroa, M.J.; Ribeiro, S.K. Energy for road passenger transport and sustainable development: Assessing policies and goals interactions. Curr. Opin. Environ. Sustain. 2013, 5, 152-162. [CrossRef]

7. Macmillan, A.; Smith, M.; Witten, K.; Woodward, A.; Hosking, J.; Wild, K.; Field, A. Suburb-level changes for active transport to meet the SDGs: Causal theory and a New Zealand case study. Sci. Total Environ. 2020, 714, 136678. [CrossRef]

8. Castán Broto, V. Urban Governance and the Politics of Climate change. World Dev. 2017, 93, 1-15. [CrossRef]

9. How ICLEI Was Created. Available online: https://sustainablefreedomlab.org/wp-content/uploads/2015/11/How-ICLEI-was -created.pdf (accessed on 7 September 2021).

10. C40. Available online: https://www.c40.org/about (accessed on 7 September 2021).

11. ICLEI. Available online: https:/ /iclei.org/en/About_ICLEI_2.html (accessed on 7 September 2021).

12. Plano Municipal de Mitigação e Adaptação às Mudanças Climáticas_PlanClima. Available online: https://mid.curitiba.pr.gov. br/2020/00306556.pdf (accessed on 7 September 2021).

13. Curitiba Population 2021 (Demographics, Maps, Graphs). 2021. Available online: https://worldpopulationreview.com/world-ci ties/curitiba-population (accessed on 8 October 2021).

14. Duarte, F.; Gadda, T.; Moreno Luna, C.A.; Souza, F.T. What to expect from the future leaders of Bogotá and Curitiba in terms of public transport: Opinions and practices among university students. Transp. Res. Part F Traffic Psychol. Behav. 2016, 38, 7-21. [CrossRef]

15. Carvalho, L.; Mingardo, G.; Haaren, J. Van Green Urban Transport Policies and Cleantech Innovations: Evidence from Curitiba, Göteborg and Hamburg. Eur. Plan. Stud. 2012, 20, 375-396. [CrossRef]

16. Rode, P.; Heeckt, C.; Da, N.; Research, C.; Ulterino, M.; Maxwell, K.; Gençsü, I.; Whitley, S. National Transport Policy and Cities: Key Policy Interventions to Drive Compact and Connected Urban Growth; Coalition for Urban Transitions: London, UK; Washington, DC, USA, 2019.

17. James, K.L.; Randall, N.P.; Haddaway, N.R. A methodology for systematic mapping in environmental sciences. Environ. Evid. 2016, 5, 7. [CrossRef]

18. Gough, D.; Oliver, S.; Thomas, J. (Eds.) An Introduction to Systematic Reviews; SAGE Publications Ltd.: Thousand Oaks, CA, USA, 2021.

19. Vinuesa, R.; Azizpour, H.; Leite, I.; Balaam, M.; Dignum, V.; Domisch, S.; Felländer, A.; Langhans, S.; Tegmark, M.; Nerini, F.F. The role of artificial intelligence in achieving the Sustainable Development Goals. Nat. Commun. 2020, 11, 233. [CrossRef]

20. Fuso Nerini, F.; Tomei, J.; To, L.S.; Bisaga, I.; Parikh, P.; Black, M.; Borrion, A.; Spataru, C.; Castán Broto, V.; Anandarajah, G.; et al. Mapping synergies and trade-offs between energy and the Sustainable Development Goals. Nat. Energy 2018, 3, 10-15. [CrossRef]

21. Rhys-Tyler, G.A.; Legassick, W.; Bell, M.C. The significance of vehicle emissions standards for levels of exhaust pollution from light vehicles in an urban area. Atmos. Environ. 2011, 45, 3286-3293. [CrossRef]

22. Kishimoto, P.N.; Karplus, V.J.; Zhong, M.; Saikawa, E.; Zhang, X.; Zhang, X. The Impact of Coordinated Policies on Air Pollution Emissions from Road Transportation in China I MIT Global Change. Available online: https://globalchange.mit.edu/publication /16279 (accessed on 7 September 2021).

23. ICCT. A Technical Summary of Euro 6/VI Vehicle Emission Standards I International Council on Clean Transportation. 2016. Available online: https://theicct.org/publications/technical-summary-euro-6vi-vehicle-emission-standards (accessed on 7 September 2021).

24. Shindell, D.; Faluvegi, G.; Walsh, M.; Anenberg, S.C.; Van Dingenen, R.; Muller, N.Z.; Austin, J.; Koch, D.; Milly, G. Climate, health, agricultural and economic impacts of tighter vehicle-emission standards. Nat. Clim. Chang. 2011, 1, 59-66. [CrossRef]

25. Knecht, W. Diesel engine development in view of reduced emission standards. Energy 2008, 33, 264-271. [CrossRef]

26. ICCT. Brazil PROCONVE L-7 and L-8 Emission Standards for Light-Duty Vehicles; ICCT: San Francisco, CA, USA, 2018.

27. Malina, C.; Scheffler, F. The impact of Low Emission Zones on particulate matter concentration and public health. Transp. Res. Part A Policy Pract. 2015, 77, 372-385. [CrossRef] 
28. Holman, C.; Harrison, R.; Querol, X. Review of the efficacy of low emission zones to improve urban air quality in European cities. Atmos. Environ. 2015, 111, 161-169. [CrossRef]

29. Gehrsitz, M. The effect of low emission zones on air pollution and infant health. J. Environ. Econ. Manag. 2017, 83, 121-144. [CrossRef]

30. Ellison, R.B.; Greaves, S.P.; Hensher, D.A. Five years of London's low emission zone: Effects on vehicle fleet composition and air quality. Transp. Res. Part D Transp. Environ. 2013, 23, 25-33. [CrossRef]

31. Dablanc, L.; Montenon, A. Impacts of Environmental Access Restrictions on Freight Delivery Activities: Example of Low Emissions Zones in Europe. Transp. Res. Rec. 2015, 2478, 12-18. [CrossRef]

32. Wolff, H. Keep Your Clunker in the Suburb: Low-Emission Zones and Adoption of Green Vehicles. Econ. J. 2014, 124, F481-F512. [CrossRef]

33. Sims, H.; Hollingworth, B. Measures to Reduce Greenhouse Gas Emissions from Urban Goods Movement-A Review of Current Initiatives. Available online: https:/ / ctrf.ca/wp-content/uploads/2014/07/48HollingworthSimsGreehouseGasEmmissions.pdf (accessed on 7 September 2021).

34. Glazener, A.; Khreis, H. Transforming Our Cities: Best Practices Towards Clean Air and Active Transportation. Curr. Environ. Health Rep. 2019, 6, 22-37. [CrossRef]

35. Battista, G.A.; Manaugh, K. Examining social inclusion among pedestrian plans in Canada. Can. Geogr. 2019, 63, 663-675. [CrossRef]

36. Gilderbloom, J.I.; Riggs, W.W.; Meares, W.L. Does walkability matter? An examination of walkability's impact on housing values, foreclosures and crime. Cities 2015, 42, 13-24. [CrossRef]

37. de Sousa, A.A.; Sanches, S.P.; Ferreira, M.A.G. Perception of Barriers for the Use of Bicycles. Procedia Soc. Behav. Sci. 2014, 160, 304-313. [CrossRef]

38. IPPUC. Plano de Estrutura Cicloviária está Disponível no Site do Ippuc_Prefeitura de Curitiba. Available online: https://www.cu ritiba.pr.gov.br/noticias/plano-de-estrutura-cicloviaria-esta-disponivel-no-site-do-ippuc/49249 (accessed on 7 September 2021).

39. IPPUC. Novo Inter 2: Curitiba rumo à Eletromobilidade-Prefeitura de Curitiba. Available online: https://www.curitiba.pr.gov. $\mathrm{br} /$ noticiasespeciais/novo-inter-2-caminho-aberto-a-eletromobilidade/18 (accessed on 7 September 2021).

40. Wang, L.; Xu, J.; Qin, P. Will a driving restriction policy reduce car trips?-The case study of Beijing, China. Transp. Res. Part A Policy Pract. 2014, 67, 279-290. [CrossRef]

41. Roh, M.; Jeon, S.; Kim, S.; Yu, S.; Heshmati, A.; Kim, S. Modeling Air Pollutant Emissions in the Provincial Level Road Transportation Sector in Korea: A Case Study of the Zero-Emission Vehicle Subsidy. Energies 2020, 13, 3999. [CrossRef]

42. Thorne, Z.; Hughes, L. Evaluating the effectiveness of electric vehicle subsidies in Canada. Procedia Comput. Sci. 2019, 155, 519-526. [CrossRef]

43. Curitiba I Data Portal for Cities. Available online: https://dataportalforcities.org/latin-america-caribbean/brazil/parana/curiti ba (accessed on 7 September 2021).

44. IEA. Brazil-Countries \& Regions-IEA. Available online: https:/ / www.iea.org/countries/brazil (accessed on 7 September 2021).

45. UC Davis. Impact of the Clean Vehicle Rebate Project's Increased Rebates for Low-and Moderate-Income Individuals on California's ZEV Market; UC Davis: Davis, CA, USA, 2019.

46. McDonagh, J. Transport policy instruments and transport-related social exclusion in rural Republic of Ireland. J. Transp. Geogr. 2006, 14, 355-366. [CrossRef]

47. Fu, M.; Andrew Kelly, J. Carbon related taxation policies for road transport: Efficacy of ownership and usage taxes, and the role of public transport and motorist cost perception on policy outcomes. Transp. Policy 2012, 22, 57-69. [CrossRef]

48. Cats, O.; Susilo, Y.O.; Reimal, T. The prospects of fare-free public transport: Evidence from Tallinn. Transportation 2016, 44, 1083-1104. [CrossRef]

49. Cadena, P.C.B.; Vassallo, J.M.; Herraiz, I.; Loro, M. Social and Distributional Effects of Public Transport Fares and Subsidy Policies: Case of Madrid, Spain. Transp. Res. Rec. 2016, 2544, 47-54. [CrossRef]

50. Hess, D.B. Decrypting fare-free public transport in Tallinn, Estonia. Case Stud. Transp. Policy 2017, 5, 690-698. [CrossRef]

51. Cools, M.; Fabbro, Y.; Bellemans, T. Free public transport: A socio-cognitive analysis. Transp. Res. Part A Policy Pract. 2016, 86, 96-107. [CrossRef]

52. Wu, F.; Xue, Y. Innovations of Bike Sharing Industry in China-A Case Study of Mobike's Station-Less Bike Sharing System. 2017. Available online: http://kth.diva-portal.org/smash/get/diva2:1111732/FULLTEXT01.pdf (accessed on 7 September 2021).

53. Creutzig, F.; Franzen, M.; Moeckel, R.; Heinrichs, D.; Nagel, K.; Nieland, S.; Weisz, H. Leveraging digitalization for sustainability in urban transport. Glob. Sustain. 2019, 2, e14. [CrossRef]

54. Martin, E.W.; Chan, N.D.; Shaheen, S.A. How Public Education on Ecodriving Can Reduce Both Fuel Use and Greenhouse Gas Emissions. Transp. Res. Rec. 2012, 2287, 163-173. [CrossRef]

55. Barth, M.; Boriboonsomsin, K. Energy and emissions impacts of a freeway-based dynamic eco-driving system. Transp. Res. Part D Transp. Environ. 2009, 14, 400-410. [CrossRef]

56. Allison, C.K.; Stanton, N.A. Eco-driving: The role of feedback in reducing emissions from everyday driving behaviours. Theor. Issues Ergon. Sci. 2018, 20, 85-104. [CrossRef]

57. Barkenbus, J.N. Eco-driving: An overlooked climate change initiative. Energy Policy 2010, 38, 762-769. [CrossRef] 
58. European Comission. Green Public Procurement-Transport Technical Background Report; European Comission: Brussels, Belgium, 2011.

59. Aldenius, M.; Khan, J. Strategic use of green public procurement in the bus sector: Challenges and opportunities. J. Clean. Prod. 2017, 164, 250-257. [CrossRef] 